\author{
JAROSEAW PAEKA \\ History Meeting House, Warsaw
}

\title{
THE VISTULA PROGRAMME. NUCLEAR WEAPONS FOR THE POLISH PEOPLE'S ARMY IN CASE OF WAR
}

\begin{abstract}
During the Cold War (most certainly in 1970-90) nuclear weapons were stored in Poland under the strict control of the Soviet Army. In case of war these weapons were to have been made available to Polish Army units.

Ke y w or ds: Polish People's Army, Warsaw Pact, nuclear weapons, Cold War, Vistula Programme, Soviet Army.
\end{abstract}

The concept of using the Polish Armed Forces in an armed conflict during the Cold War stemmed from the Soviet Union's military doctrine. Although the strategic plans of the Soviets have not been made public, we can certainly say that it was an offensive doctrine. ${ }^{1}$ It was influenced by the experience of the Second World War, development of the post-war art of war as well as technological developments, primarily the emergence of huge amounts of nuclear weapons in both the West and the East. To put it briefly, the doctrine provided for a powerful nuclear missile attack on the enemy's military and industrial facilities as well as a launch of offensive operations on land and sea to crush the enemy's armed forces completely and seize its territory. ${ }^{2}$ Thus nuclear weapons were to play a decisive role in the conflict - as was also defined by the United States, which was also expanding its nuclear weapon arsenal. ${ }^{3}$

${ }^{1}$ Jerzy M. Nowak, Od hegemonii do agonii. Upadek Układu Warszawskiego - polska perspektywa, Warsaw, 2011, pp. 46, 226.

2 Jerzy Kajetanowicz, Polskie wojska ladowe w latach 1945-1960. Skład bojowy struktury organizacyjne uzbrojenie, Toruń, 2005, pp. 294-95.

${ }^{3}$ Michał Trubas writes that offensive operations were planned both in the East and in the West. See 'Radziecka bron jądrowa w Polsce w latach 1967-1989', in Mity i legendy w polskiej historii wojskowości, ed. Wiesław Caban and Józef Smoliński, 2 vols, Kielce, 2014, vol. 2, pp. 276-85. A similar opinion has been expressed by Jerzy Kajetanowicz, according to whom if the plans to deploy the Polish People's Army were 
The Polish doctrine and military planning were subordinated to the Soviet objectives and dependent on Poland's position within the Warsaw Pact. From the early 1960s successive brigades and battalions of operational-tactical missiles were created in the Polish People's Army. At that time the army acquired missile systems capable of deploying mass destruction weapons on the operational level over a distance of up to $300 \mathrm{~km}$, and on the tactical level - up to $65 \mathrm{~km}$. The air force received versions of MiG-21 and Su-7 aircraft capable of carrying nuclear missiles. In addition, new units were established to deliver such weapons to the carriers. Polish staff officers practised on maps how the so-called Polish Front (Sea Front), comprising three general armies, air force and navy units, would attack Denmark, northern Germany and Holland as part of an offensive operation. Nuclear weapons were a key element of these war games. ${ }^{4}$ Moscow's and Warsaw's initial plan was that when the war broke out, these deadliest of weapons would be delivered to the Polish missile units and air force from storage sites in the Soviet Union.

Nuclear weapons found their way into Poland probably in the early 1960s, when the Northern Group of the Soviet Armed Forced stationed in Poland acquired aircraft capable of carrying such weapons. It was at that time that the first storage site for nuclear warheads was built on the airfield in Szprotawa (a town near Poland's western border). ${ }^{5}$ More such facilities to store nuclear warheads were built in Poland and other Warsaw Pact countries, where Soviet troops were stationed, over the following decades. However, these warheads were destined for the Soviet army. ${ }^{6}$

offensive in nature, this stemmed mainly from the 'military strategy adopted in the Cold War period by the Warsaw Pact states as well as NATO'. See 'Mity w historii Wojska Polskiego w okresie Polskiej Rzeczypospolitej Ludowej', in Mity i legendy w polskiej historii wojskowości, ed. Caban and Smoliński, vol.2, p. 359. We know neither the Soviets' nor the NATO states' operational plans, but the Polish operational plans (based on those of the Soviets) were exclusively offensive from the 1960s until the mid-1980s. It was not until 1986 that Poland's operational plan began to provide for defence as well. It seems that the change resulted from the country's economic problems, and, above all, from the economic crisis and perestroika experienced by the Soviet Union at the time.

${ }^{4}$ Jerzy Kajetanowicz, Wojsko Polskie w systemie bezpieczeństwa państwa 1945-2010, Częstochowa, 2013, pp. 45-48; Paweł Piotrowski, 'Front Polski - próba wyjaśnienia zagadnienia', Wrocławskie Studia z Historii Najnowszej, 6, 1999, pp. 223-24; Sztab Generalny (Główny) Wojska Polskiego 1918-2003, ed. Tadeusz Panecki, Franciszek Puchała and Jan Szostak, Warsaw, 2003, pp. 233-34.

${ }^{5}$ Even earlier, probably in 1957-58, the Soviet nuclear weapons found their way into the German Democratic Republic, where Soviet troops were stationed as well.

${ }^{6}$ Tomasz Szulc and Krzysztof Nicpon, 'Magazyny broni jądrowej na terytorium Polski', Poligon, 2007, 3, pp. 62-77. 
Unfortunately, we do not know how many such facilities were built and what kind of weapons were stored there. In a 1979 report the American intelligence said that there were 23 storage sites in Central and Eastern Europe, outside Soviet Union, where nuclear weapons were kept. Five of them were located in Poland ${ }^{7}$ (including the storage sites referred to further on in the article).

To a large extent this was a result of the military situation in Europe. Seeking to eliminate the Soviet advantage in conventional weapons, from the mid-1950s the United States began to place nuclear weapons in Western Europe. This was described as the principle of the so-called great equalizer. ${ }^{8}$ As a result by the mid-1970s the Americans had over seven thousand tactical nuclear weapons in Western Europe. ${ }^{9}$ They remained at the disposal of the American army and could be provided to other NATO countries only in case of war. Given the ongoing arms race, in the mid-1960s the Kremlin, too, decided that its strategy concerning the storage of mass destruction weapons in Central and Eastern Europe should be changed and that it should make its nuclear arsenal available (or, rather, be ready to make it available) to its allies to a limited extent.

It was most likely in February 1965 that military exercises were organized to verify how the delivery of nuclear weapons to Polish units would look in practice. ${ }^{10}$ The exercises were organized on the highest level, under the command of General Pavel Batov, Chief of Staff of the Unified Warsaw Pact Forces. Nuclear warheads were to be delivered to Poland via three different routes and by means of three different modes of transport. A ship arrived at the port of Ustka from which the warheads were transported to the training ground in Drawsko and to the airfield in Słupsk. A supply of the warheads was delivered from Brest on a train to the training ground in Borne Sulinowo. Finally, four Soviet Su-7 planes flew into the Debrzno airfield carrying nuclear bombs. On 26 February 1965 a display of ready to launch missiles was held in Karwice, on the premises of the Drawsko training ground, in the presence of over 100 high level Polish

${ }^{7}$ Warsaw Pact Forces Opposite NATO, Volume I, Summary Estimate, pp. 45-46, 〈http://www.foia.cia.gov/sites/default/files/document_conversions/1700321/1979 -01-31a.pdf $\rangle$ [accessed 25 September 2016].

${ }^{8}$ The term referred to the popular nineteenth-century Colt revolver, which apparently eliminated opponents' physical advantage.

${ }^{9}$ Stanisław Zarychta, Broń jądrowa w kształtowaniu bezpieczeństwa 1945-2015, Warsaw, 2016, p. 230.

${ }^{10}$ According to Michał Trubas, the exercises, code-named Narew, were conducted in February and March 1965. In fact, exercises with such a code name were held in June 1965. Similar exercises were also conducted in other Warsaw Pact countries. Trubas, 'Radziecka broń jądrowa', p. 279. 
officers. The conclusion of the exercise was that each of these solutions had its weaknesses. First of all, the transport took too long and could be an easy target for the enemy. ${ }^{11}$

A decision was, therefore, made in Moscow that the nuclear materials for the Polish People's Army in case of war would be stored directly within Poland's territory. Such a solution considerably shortened the time needed to prepare the nuclear weapons for use by the allied army. The programme was code-named Vistula (in some documents it was marked with the symbol ' 3000 ') and was one of the best guarded secrets in communist Poland. The present article is based on the documents of the Vistula Programme from the Central Military Archives made available to historians in 2006 and currently kept in the Institute of National Remembrance. The documents fill only three files and do not make up a separate collection. ${ }^{12}$ It seems that changes of the location of the documents and the lack of a separate collection have been the reasons why historians have used them very rarely, and why the issue has been discussed mainly in sensationalist or journalistic terms so far. The information from the documents presented in the article is supplemented with documents dealing with the Polish military planning. This constitutes a very modest source base, as a result of which aspects of the topic in question are still a matter of guesswork. The doubts will not be dispelled until documents from the Ministry of Defence and General Staff of the Soviet Union have been made public, which, however, can hardly be expected in the nearest future.

In the autumn of 1966 a Polish-Soviet commission was set up and in November that year it carried out a reconnaissance of selected locations where storage sites for nuclear warheads could be built. Initially, the commission selected four locations: near Białogard, Wałcz, Wędrzyn and Bolesławiec (all four are near Poland's western border). When choosing the potential locations, the commission paid attention to the number and quality of internal transport routes, proximity to railways and railway stations as well as camouflage possibilities - the special sites were to be located in a dense forest. We can also read in the documents that in order to 'create better conditions of secrecy [...], residential buildings for the families of officers should be located near the Soviet Army's garrisons'. Four questionnaires featuring several dozen criteria were com-

${ }^{11}$ This is how the exercises are described by Tomasz Pompowski and Paweł Piotrowski. See 'Polska miała arsenał broni nuklearnej', Dziennik, 26 January 2007, 〈http://wiadomosci.dziennik.pl/polityka/artykuly/198972,polska-miala-arsenal -broni-nuklearnej.html> [accessed 26 September 2016].

${ }^{12}$ The numbers of the files are: AIPN 1405/322, AIPN 1405/323 and AIPN $1405 / 324$. 
piled and on their basis the special sites were eventually chosen. In addition to those mentioned above, the remaining questions concerned field, sanitary and climate conditions, water supply as well as difficulties in building sewage and communication networks. The decisions about the location were to be taken after the results of structure drilling were obtained.${ }^{13}$ In the end three locations were chosen: Podborsko near Białogard (storage site code-named 3001 or Training Ground), Brzeźnica-Kolonia near Jastrowie (3002, Camp) and Templewo near Trzemeszno Lubuskie (3003, Fence).

The main agreement concerning the construction of the sites where nuclear weapons for the Polish People's Army in case of war were to be stored was signed on 25 February 1967. On behalf of the Polish side it was signed by Marshal Marian Spychalski, of the Soviet side - Marshal Andrei Grechko, Deputy Minister of Defence and, at the same time, commander-in-chief of the Warsaw Pact Unified Forces. Its preamble read that it was an agreement 'between the Government of the Polish People's Republic and the Government of the Union of Soviet Socialist Republics on measures to increase combat readiness' (it was put slightly differently elsewhere: 'to further increase combat readiness'). The plan was for three nuclear weapon storage sites to be completed by 1 July 1969. ${ }^{14}$ Significantly, the decision to build the storage sites was not reflected in any decision made by Poland's party and government leadership. It seems that the proposal was submitted by the Kremlin only for formal approval by the authorities of the Polish People's Republic. Moscow signed a similar agreement with Czechoslovakia in autumn 1965 (Operation 'Sycamore', agreement on three sites), with Bulgaria in late 1965 and early 1966 (three sites) as well as the German Democratic Republic (two sites) and Hungary (one site). ${ }^{15}$ We do not know the details of these arrangements; in any case, nuclear weapons did find their way into these countries.

Each of the sites to be built in Poland was to have two reinforced special facilities with rooms designated for 'programme' work, that is storage and

13 'stworzenia lepszych warunków tajności [...], budynki mieszkalne dla rodzin kadry wojskowej wskazanym jest lokalizować w rejonach garnizonów Wojsk Radzieckich', AIPN 1405/323, Protokół sporządzony 13 XI 1966 r. w Warszawie, fols 5-8, and Ankiety rejonów 1-4, fols 14-62.

14 [agreement] 'między Rządem Polskiej Rzeczpospolitej Ludowej a Rządem Związku Socjalistycznych Republik Radzieckich o środkach podjętych w zakresie podwyższenia gotowości bojowej wojsk', 'w interesie dalszego zwiększenia gotowości bojowej’, AIPN 1405/324, Porozumienie między Rządem Polskiej Rzeczpospolitej Ludowej a Rządem Związku Socjalistycznych Republik Radzieckich, 25 February 1967, fols 470-73.

${ }^{15}$ Szulc and Nicpoń, 'Magazyny broni jądrowej', pp. 62-77. 
handling of nuclear warheads, two storage facilities for explosives and detonators, cavities for radioactive waste and a fire fighting water tank. There were plans to construct a building to house the staff, communication centre as well as quarters for 120 soldiers with a ten-bed sick room. ${ }^{16}$ Another building was to house a kitchen-dining room (cinema room), where 120 meals could be prepared, a cafe and a mess for 20 officers. In addition, there were plans to construct five buildings with a total of 60 flats, a garage for 80 vehicles (including 25 heated spots), ten-post guard house with a pass office and room to supervise the special fence, sanitary and technical facilities, including boiler rooms with baths, sewage system and a fire fighting water tank. Each facility was to be surrounded by a 2.5-metre-high reinforced concrete fence topped with barbed wire. ${ }^{17}$

The main agreement was followed by another agreement, signed on 13 March 1967, on the delivery from the Soviet Union of material and equipment for the construction of the facilities. In addition, the Soviet side was to provide free designs of the special facilities, including the nuclear weapon storage facilities, as well as cavities for radioactive waste. They were to be built as "monolithic structures of reinforced concrete mark 300, class A-II'. The Soviet side was also to deliver, 'for a fee', special technical equipment to control, assemble and handle nuclear ammunition in the special storage sites. ${ }^{18}$ The Poles were to prepare all the design intents as well as designs for the technical, utility and residential zones in each of the sites. ${ }^{19}$

The construction was carried out by Polish troops from engineering battalions. Successive facilities were built by the 33rd Engineering Regiment from Gdynia-Oksywie (3001), the 31st Engineering Regiment from Piła (3002), the 27th Engineering Regiment from Gniezno (3003) as well as the 2nd Communication Engineering Regiment from Zgierz. The construction works and all soldiers involved had to be vetted by the Internal Mili-

${ }^{16}$ In the end at each site the building was to house 110 soldiers and have a eleven-bed sick room.

${ }^{17}$ AIPN 1405/324, Wykaz budynków i urządzeń planowanych do budowy w każdym obiekcie specjalnym. Annex 1 to the Porozumienie (Agreement) of 25 February 1967, fols 475-76.

${ }^{18}$ According to Annex 2 to the Agreement, the Soviet Union was to deliver to each facility two sets of "control, measuring and assembly equipment for control and assembly work featuring nuclear ammunition (special desks and stands, tools, test equipment, assembly stands, special holders) [...]; special laboratory equipment, instruments, tools, tables and frames for working with nuclear ammunition [...]; special hoisting equipment with rigging for handling nuclear ammunition in storage sites (special three-ton lifts, electric lifts, special beams)'.

${ }^{19}$ AIPN 1405/324, Protokół w sprawie projektowania obiektów w rejonach nr 1,2, 3; 13 March 1967, fols 349-53. 
tary Intelligence Service. In order to hide the real purpose of the sites, the official communication was that they were to serve as quarters for Soviet communication battalions. The sites were not marked on any topographic plans and access to them was obviously denied to forestry administration representatives. Buildings were to be covered with camouflage nets, while internal paths and squares made of concrete were to be covered with a layer of soil making them look like the ground around them.

The construction of the facilities under the Vistula Programme lasted slightly longer than the agreement provided for - it was completed in September and October 1969. Towards the end of that year the facilities went through an acceptance procedure by a Polish-Soviet working commission. In each case the quality of construction and assembly work was graded as 'excellent'. Minor, isolated defects were to be removed in the immediate future both by the Polish side and by the Soviet units that were to use the facilities - for example, in some cases the Soviet side had failed to deliver some electric equipment or 'automatics'. Yet the defects were of no major significance to the future use of the sites. The acceptance was endorsed by the acting Chief of Staff, General Eugeniusz Molczyk. ${ }^{20} \mathrm{~A}$ few days later all sites were accepted by a Polish-Soviet State Commission headed by General Jarosław Słupski and, on the Soviet side, General Sit Epifanov. Their results were endorsed by General Wojciech Jaruzelski, the then Minister of National Defence, and Marshal Andrei Grechko, Minister of Defence of the Soviet Union.

Site 3001 was the biggest, extending over an area of 180 ha, with 110 ha behind a double barbed wire fence. ${ }^{21}$ The construction and equipment cost the Polish side nearly 62,600,000 Polish zlotys. ${ }^{22}$ Site 3002 occupied an area of 147 ha and its main part surrounded by a double barbed wire fence -91 ha. ${ }^{23}$ It cost nearly $58,340,000$ Polish zlotys..$^{24}$ Finally, the third and smallest site extended over 140 ha, but its main part occupied 99 ha. It cost nearly 56,900,000 Polish zlotys. ${ }^{25}$ Thus the Poles paid nearly 178 million zlotys in total for the construction of all the sites.

${ }^{20}$ AIPN 1405/322, Protokół komisji roboczej odbioru obiektu 3001, fol. 18; Protokół komisji roboczej odbioru obiektu 3002, fol. 174; Protokół komisji roboczej odbioru obiektu 3003, fol. 70; all protocols are dated 1 December 1969.

${ }^{21}$ AIPN 1405/322, Protokół Państwowej Komisji odbioru i przekazania do eksploatacji zakończonej budowy obiektu 3001,11 December 1969, fols 167-72.

${ }^{22}$ AIPN 1405/322, Zamówienie kosztów zam. 3001, 28 April 1970, fol. 371.

${ }^{23}$ AIPN 1405/322, Protokół Państwowej Komisji odbioru i przekazania do eksploatacji zakończonej budowy obiektu 3002,11 December 1969, fols 167-72.

${ }^{24}$ AIPN 1405/322, Zamówienie kosztów zam. 3002, 28 April 1970, fol. 349.

${ }^{25}$ AIPN 1405/322, Zamówienie kosztów zam. 3003, 28 April 1970, fol. 415. 
After the construction was completed, on 28 February 1970 an agreement was signed concerning the use of the sites. The previous agreement, from 1967, read that the 'sites are the property of the Polish People's Republic'. The 1970 agreement made it more specific, saying the Polish People's Republic owned only 'the buildings and stationary equipment installed in them'. All sites were handed over to the Soviet Command for 'temporary use' under the Agreement of 16 June 1958 on the mode and conditions of temporary stationing of Soviet armed forces in Poland. The Soviet side undertook to 'maintain, service and prepare nuclear ammunition for delivery and to protect it'. Thus Soviet units were to be stationed on the sites and their 'supervision, inspection, verification of combat readiness and combat training programme were to be conducted by the Soviet side'. Security for the sites, too, was provided for by Soviet soldiers. In addition, "[the] area providing access to the external fence will constitute a prohibited area. [...] Should site security be strengthened and defence organized, the necessary forces and measures will be allocated by the Soviet side. The mode of call and operation of these forces will be determined by the Command of the Northern Group of the Armed Forces and communicated to the commanders of the units deployed on the sites'. Telegraph and telephone communication was to be set up between the sites and the Polish General Staff as well as between the sites and the Staff of the Northern Group of Soviet Armed Forces in Legnica, and the nearest Soviet army unit. ${ }^{26}$

The programme was classified as top secret. Immediately after the sites were handed over to the Soviet side, the Polish General Staff ordered that 'all correspondence and any documents featuring the content and markings of the "3000" project be discontinued'. The documents already produced were to be mostly destroyed. In addition, 'documents to be kept further should be limited only to those that were essential'. All were to be put into sealed packets/packages and kept only in the Central Units of the Ministry of Defence, with the symbol on the packets/packages being changed

26 'kontrola ich działalności, inspekcjonowanie, sprawdzanie gotowości bojowej i wykonania programów szkolenia bojowego będą dokonywane przez stronę radziecką’; 'Na podejściach do zewnętrznego pierścienia ogrodzenia obiektów (płotu zewnętrznego) będzie ustalona strefa zakazana. [...] W wypadku konieczności wzmocnienia ochrony i organizacji obrony obiektów, niezbędne siły i środki do tych celów będą wydzielone przez Stronę Radziecką. Sposób wezwania i działania tych sił zostanie określony przez Dowództwo Północnej Grupy Wojsk i doprowadzony do dowódców jednostek, rozmieszczonych na tych obiektach', AIPN 1405/322, Protokół do porozumienia między Rządem Związku Socjalistycznych Republik Radzieckich a Rządem Polskiej Rzeczypospolitej Ludowej z dnia 25 II 1967 r., 28 February 1970, fols 373-79. 
to ' 2345 '. The instruction was to be given to various units only orally. ${ }^{27}$ Thus in the late 1960s the true purpose of the sites was known only to twelve Polish high ranking officers, including General Jerzy Bordziłowski (Soviet officer delegated during the war from the Red Army to the Polish People's Army), the Chief Training Inspector, and General Wojciech Jaruzelski, Chief of the General Staff. In the following years the information was passed to strictly selected highest ranking officers, Chiefs of the General Staff, Chief Training Inspectors, heads of the missile force, air force etc. Upon appointment to their high posts, each was given access to the Vistula Programme documents and signed a declaration of absolute secrecy. The situation continued almost till the very end of the Warsaw Pact. The last entry confirming the reading of the Vistula Programme file comes from 17 March 1990, when General Franciszek Puchała, head of operations of the General Staff, handed over the Vistula Programme documents at the end of his term in office to his successor, General Marian Robełek, who signed the absolute secrecy declaration. ${ }^{28}$

It seems, however, that the Polish commanders were not quite sure how the process of transferring nuclear warheads to the Polish Front would look like in detail and when exactly this would happen. In August 1967 Moscow explained that after the construction of the Vistula Programme sites it would be possible to deliver three nuclear warheads per each tactical and operational-tactical missile launcher as well as one warhead per 'carrier' aircraft. ${ }^{29}$ All nuclear operational and strategic strikes were to be carried out by the Soviet forces. At the same time the agreement read that the 'Polish side undertakes to deliver the nuclear ammunition from the special storage sites to field missile bases of the Polish Armed Forces and, therefore, to maintain a required number of vehicles designated for the purpose in the missile delivery units'. ${ }^{30}$ It should also maintain field missile bases near the sites and thus, as was defined in the

${ }^{27}$ AIPN 1405/322, Zarządzenie szefa Sztabu Generalnego nr 0022/oper., 21 March 1970 , fols $328-30$.

${ }^{28}$ AIPN 1405/324, Wykazy osób, które zapoznały się z programem 'Wisła', fols 390-94.

${ }^{29}$ AIPN 1405/322, Pismo marszałka Greczko do ministra obrony narodowej marszałka Spychalskiego, 5 [?] August 1967, fol. 549.

30 'strona polska bierze na siebie obowiązek dostarczenia amunicji jądrowej od składów specjalnych do polowych technicznych baz rakietowych Wojska Polskiego, w związku z czym utrzymuje ona w pododdziałach dowozu rakiet niezbędną ilość samochodów specjalnie do tego celu przeznaczonych', AIPN 1405/324, Porozumienie między Rządem Polskiej Rzeczpospolitej Ludowej a Rządem Związku Socjalistycznych Republik Radzieckich, 25 February 1967, fols 470-73. Field Missile Transport Bases (the Pomeranian Military District had two such units) as well as battalions for missile delivery were created in each of the three military districts. 
agreement, 'required number of vehicles designated for the purpose'. The missile forces of the Polish People's Army had special units needed to secure and transport such weapons. In the 1960s Field Missile Transport Bases (PTBR) were set up in each of the three military districts: the 11th PTBR was stationed in Skwierzyn, in the Silesian Military District; the 21st PTBR was stationed in Ornet, in the Warsaw Military District, while the Pomeranian Military District had two such units - the 18th PTBR in Szczecin and the 15th PTBR in Miedwie near Stargard Szczeciński. Special battalions for missile delivery were created as well.

However, these were quite vague declarations from the Soviet side. According to the 1970 document, the mode of nuclear ammunition issue and subordination of assembly units to the Polish Army for the duration of the war would be determined during successive negotiations between the Polish and Soviet General Staffs. However, nothing of the sort happened for the following fifteen years, until 1986. This enabled the Soviet side to interpret the agreement with Poland on the transfer of nuclear weapons in case of war as it wished. When asked by the Polish side about the details concerning the execution of the agreement, representatives of the Soviet Army apparently replied that the warheads would be transferred in due course. We can imagine a situation when the warheads, or at least some of them, stored in the three sites would have been delivered to Soviet and not Polish troops. All the more so given the fact that in the mid-1970s one additional concrete bunker (of the 'Granite' type) was built at each of the three sites, which considerably expanded their storage capacity. It seems that if nuclear warheads (which may have been designated for other purposes, of course) were stored in them, they would have been given to Soviet carriers stationed in Poland. The bunkers built in 1967-70 were large enough to store all nuclear warheads earmarked only for the Polish forces. ${ }^{31}$ What speaks in favour of such a hypothesis is the fact that among the Vistula Programme documents produced by the Polish General Staff there is no agreement documenting any expansion of the facilities and thus defining the use of the 'Granite' bunkers for the storage of nuclear warheads earmarked for Polish carriers. This expansion may have contravened the additional agreement of 1970, as this documents states that 'any alteration and change in the buildings, any forest clearing at the sites or near them shall be carried out only on the basis of consent of both Parties'. ${ }^{32}$

${ }^{31}$ Szulc and Nicpoń, 'Magazyny broni jądrowej', p. 75.

${ }^{32}$ AIPN 1405/322, Protokół do porozumienia między Rządem Związku Socjalistycznych Republik Radzieckich a Rządem Polskiej Rzeczypospolitej Ludowej z dnia 25 II 1967 r., 28 February 1970, fols 373-79. 
Yet from at least the late 1950s use of nuclear weapons was taken into account in Polish scenarios of strategic-operational exercises as well as operational plans, obviously consulted with and approved by Moscow. It seems that the first such exercises, or a war game in fact, were conducted in 1959, when, according to the documents produced at the time, the Masurian Front (later Sea Front) was to receive forty nuclear warheads for the purpose of offensive operations. ${ }^{33}$ In 1965 the first operational plan was approved. Its title was 'Plan of an offensive operation of the Sea Front' and it mentioned the use of 91 nuclear warheads for the purpose of an offensive against NATO forces. In another operational plan, approved in 1970, the number of nuclear warheads needed for the operations of the Polish Sea Front was increased to $177 .^{34}$ Every time separate strikes of a strategic nature were to have been carried out by the Soviet troops. Obviously, an assumption was made for the purpose of military planning that NATO states, too, would use nuclear weapons in their military operations. Finally, as we can read in the third operational plan, of 1986, 'if nuclear weapons were to be used, the front [...] carries out [...] a mass nuclear strike, using 156 warheads $55 \%$ of the allocated limit'. ${ }^{35}$ However, it seems that it was by no means clear to the Polish generals how nuclear weapons would be transferred to Polish units. It was not until the 1980 s that steps were taken to make these operations more specific and to formalize them. In any case, at that time the Soviet side was increasingly willing to consult and add various written obligations associated with the functioning of the Warsaw Pact.

To this end, in February 1986, that is at a time when work on the third operational plan was coming to an end, Moscow invited Warsaw to talks about concrete ways of transferring nuclear weapons. Officers who flew to the Soviet capital at the time were General Franciszek Puchała, head of operations at the General Staff, General Włodzimierz Kwaczeniuk, head of the Missile and Artillery Force, and General Edward Ogrodowicz, head of the Armament and Electronics Service. Its seems that they had many questions and doubts, as is suggested by General Puchała's notebook filled with

${ }^{33}$ A MON, 18/91/16, Założenia operacyjne do ćwiczeń na temat: Organizacja i prowadzenie działań dywersyjno-rozpoznawczych w operacji zaczepnej Frontu, z dnia 31 VII 1959 r., fols 1-5.

${ }^{34}$ Kajetanowicz, Wojsko Polskie, pp. 46-48.

35 'w wypadku przejścia do działań z użyciem broni jądrowej, front [...] wykonuje [...] zmasowane uderzenie jądrowe, w którym wykorzystuje 156 ładunków - 55\% przydzielonego limitu', AIPN 02958/154, Plan operacyjnego użycia Sił Zbrojnych PRL na czas wojny, zatwierdzony 29 XI 1986 r., fol. 25. 
his handwritten notes from the preparations for the Moscow talks. The 'problems to be consulted' included 'landing operation on Bornholm', 'defensive operation of the Sea Front' and 'temporary bridge crossings on the Rivers Vistula and Odra'. Above all, however, the questions concerned nuclear weapons. As Puchała noted down, 'to be discussed: mode of transferring nuclear warheads from the Vistula sites to the Polish Armed Forces' PTBR ${ }^{36}$, then: 'where, how they will be delivered; how many columns, how many specialists; codes.... ${ }^{37}$ The talks were held on 13 and 14 March 1986, and led to the emergence of detailed proposals for how the Soviet troops would transfer nuclear weapons to Polish army units. This was to have been carried out following a 'special instruction of the Supreme Command of the Unified Forces via the General Staffs'. Templates for documents authorizing the receipt of the warheads were drawn up at the time as well, and were deposited with the General Staffs in Warsaw and in Moscow. ${ }^{38}$ However, these were only proposals, which must have been followed by more rounds of consultations. Finally, three years after that first meeting a document was drawn up with the details of the operations mentioned above. It was signed on 24 October 1989 by General Józef Użycki, Chief of the General Staff (the surviving document lacks the signature of the Soviet side - perhaps the document was never submitted as the Polish United Workers' Party no longer had full power in Poland at the time).

The document was prepared in connection with the preparations for a new operational plan, which this time was to be for a defensive operation of the Sea Front. It specified the way of transferring nuclear warheads, entering the relevant codes that would arm the warheads as well as the way of using the warheads. The decision to transfer the nuclear warheads was to be made by the Soviet General Staff by sending a cable to the Polish General Staff as well as an order to the commander-in-chief of the Unified Forces of the Warsaw Pact on the Western Theatre, formally the deputy of the Chief of the Soviet General Staff. The commander-in-chief would then send a cable to the commander of the Polish Sea Front. The transfer of the warheads, their installation and 'unlocking', that is armament, was to be strictly controlled by the Soviet side. After the right code

${ }^{36}$ Field Missile Bases - missile force units the task of which was to keep the missiles fully operational technically; they were also given transport tasks, together with missile delivery battalions.

${ }^{37}$ AIPN 1405/322, Zeszyt gen. Puchały Franciszka, date of entry 10 March 1986, fols $478-509$.

${ }^{38}$ AIPN 1405/322, Streszczenie dokumentu Porozumienie między Rządem Polskiej Rzeczpospolitej Ludowej a Rządem Związku Socjalistycznych Republik Radzieckich z 25 II 1967 r., 19 July 1989, fols 513-15. 
was received, the nuclear warheads were to be handed over to the Polish missile bases responsible for their transport. ${ }^{39}$ However, this did not take place in Podborsk, Brzeźnica-Kolonia or Templewo, but in areas especially designated by the Soviets (and agreed on with the Polish General Staff) for the purpose. The commander of the Polish transport unit receiving the warheads had to have a personal authorization (the document also contained a photograph of the authorized individual) signed by the Polish Minister of National Defence or Chief of the General Staff. The authorization would specify the kind of the warheads and their number. Next the Polish field missile bases would transfer the warheads to the Polish missile, artillery or air force units. They were accompanied by Soviet soldiers, who supervised and helped in the successive stages of the preparation of nuclear warheads for an attack. A nuclear strike was to be carried out after one of the following orders was received: 'Carry out the first nuclear strike immediately', 'Carry out the first nuclear strike [date and time]' and 'Enter the code for the recalibration (armament) of nuclear weapons and carry out the first nuclear strike immediately'. All orders were encrypted in the form of a code comprising one word and a string of numbers (several groups of three or four digits), for example Maple 1234 4567. All codes for issuing and arming nuclear warheads as well as carrying a nuclear strike were to be found in the so-called Package 4, which the commander of the Sea Front received upon becoming directly subordinated to the commander-in-chief of the Unified Armed Forces of the Warsaw Pact on the Western Theatre. The digits comprising the code, appropriately encrypted, were also be the key to be entered in the locking devices to arm the nuclear warheads. ${ }^{40}$ General Kwaczeniuk once said, 'who knows the signal for the reception of the warheads knows how the trumpets for the Last Judgement sound'. ${ }^{41}$

We can only try to guess what warheads were kept in the 'Polish' storage sites and how many warheads there were. Given the capacity of the sites, there may have been between 192 warheads and a maximum of 288 warheads in one site ${ }^{42}$ (excluding the 'Granite' bunkers). In his 1986 notes

${ }^{39}$ In this context the document mentions the field missile bases and not the missile delivery battalions.

${ }^{40}$ AIPN 1405/322, Rekomendacja po poradku peredachi yadernykh boyepripasov, 24 October 1989 , fols $517-27$.

${ }^{41}$ Michał Trubas, 'Wojska “jednorazowego użytku”. Relacja', Przegląd Historyczno-Wojskowy, 12, 2011, 2, p. 162.

${ }^{42}$ Some sources suggest that theoretically there may have been even as many as nearly 500 warheads. However, this applies to warheads smaller than those designated mostly for the Polish People's Army. See Szulc and Nicpoń, 'Magazyny broni jądrowej', pp. 72-73. 
before the journey to Moscow, General Puchała noted the following numbers needed by the Sea Front units to carry out a successful operation: 'Białogard' (site 3001) - 74 nuclear missiles for the 1st Army, 'Wędrzyn' (site 3003) - 87 nuclear missiles for the 2nd Army and 'Grudek' (probably a reference to site 3002) - 57 missiles, including 33 for the 4th Army and 24 for the front's reserves. This amounted to 218 warheads in total. ${ }^{43} \mathrm{We}$ also have documents produced by the Polish command and listing its requirements for nuclear warheads kept in the storage sites. On 19 June 1989 , that is two weeks after the partly free parliamentary elections featuring Solidarity, it was agreed that should the relevant orders be issued, the 'people's army' would receive 231 warheads from the three storage sites. The document was signed by General Użycki. ${ }^{44}$ According the operational plan, that is for a defensive operation of the Sea Front, drawn up that same year, the Polish units were to have 281 nuclear warheads at their disposal. As we can see, the numbers differed, but were nevertheless similar. They may have depended on the changing tactical-operational tasks of the Polish front and thus changing resources allocated for the purpose. It can be said, however, that the numbers were most certainly agreed on with the Soviet command. This means that this was the minimum number of nuclear warheads stored in sites 3001, 3002 and 3003. The nuclear warheads were designated for the Polish People's Army's 9K72 Elbrus, OTR-21 Tochka and 9K52 Luna-M missile launchers, 2S7M Pion (Peony) self-propelled gun as well as for the air force. The power of the warheads ranged from $0.5 \mathrm{kT}$ to $500 \mathrm{kT}$ (the smallest were for the air force and self-propelled guns, the largest for the operational-tactical missiles). Nuclear warheads were to be delivered in case of war to air force units, but primarily to four so-called operational-tactical missile brigades (BROT): the 2nd Artillery Brigade from Choszczno, the 18th Artillery Brigade from Bolesławiec, the 32nd Artillery Brigade from Orzysz, the 36th (then 3rd) Artillery Brigade from Biedrusko and the 23rd Artillery Brigade from Zgorzelec. The missile force troops conducted exercises (obviously without using nuclear warheads) in Poland (the entire force) or, with part of the force, on the Kapustin Yar Soviet training ground (Astrakhan Oblast, southern Russia), on which the Soviet Union also tested intercontinental missiles and a part of which was turned into a cosmodrome.

As one officer recalled, Polish missile units were 'small, very mobile and had a huge striking potential. Kept constantly at a high combat readi-

${ }^{43}$ AIPN 1405/322, Zeszyt gen. Puchały Franciszka, date of entry 10 March 1986, fol. 490.

${ }^{44}$ AIPN 1405/322, Wzory Upoważnienia, fols 457-71. 
ness level, nearly complete in terms of combat personnel employed and very well trained, they could embark on any of their tactical and striking tasks within less than an hour'. ${ }^{45}$ Yet the Cold War was coming to an end and in 1990 the agreement of February 1967 ceased to be in force. According to its provisions, it was no longer applicable "within one year from either of the Parties expressing its wish to revoke this Agreement'. It was probably at that time that the last nuclear warheads were removed from Poland. In 1990 Moscow and Warsaw also began talks to withdraw the Northern Group of the Armed Forces of the Soviet Army from Poland.

The Vistula Programme may have constituted a violation of the Treaty on the Non-Proliferation of Nuclear Weapons (NPT), which was concluded on 1 July 1968 and the signatories of which included the Soviet Union. The treaty was also signed by the government of the Polish People's Republic; it was ratified on 12 June and entered into force on 5 March 1970. States with nuclear weapons undertook not to transfer them to other states and the treaty also imposed some obligations on Poland. Article II of the treaty was formulated quite unequivocally: 'Each nuclear-weapon State Party to the Treaty undertakes not to transfer to any recipient whatsoever nuclear weapons or other nuclear explosive devices or control over such weapons or explosive devices directly, or indirectly' ${ }^{46}$ It is likely that, like Moscow, Washington as well as several of its allies and NATO members did not observe the treaty either. From the 1950s on the United States ${ }^{47}$ would transfer tactical nuclear weapons within the territories of its allies all over the world (mostly in NATO states). The nuclear weapons were still controlled by the American Army (in Poland by the Soviet Army, and so the situation was analogous), and, therefore, representatives of the NATO states argued that there was no transfer of nuclear weapons in peacetime in fact, and that the NPT would not have applied any way in case of war. Thus, in their view, the NPT was not violated. However, this position was strongly criticized during the Cold War, all the more so given the fact that no one ever

45 [Polish missile units were] 'jednostkami małymi, bardzo mobilnymi i dysponującymi olbrzymim potencjałem rażenia. Utrzymywane ciągle w wysokiej gotowości bojowej, ukompletowane niemal do pełnych etatów wojennych i doskonale wyszkolone, mogły w ciągu kilkudziesięciu minut przystąpić do wykonania każdego z przewidzianych dla nich zadań taktycznych i ogniowych', Trubas, 'Wojska', p. 174.

${ }^{46}$ <https://treaties.un.org/doc/Publication/UNTS/Volume\%20729/volume-729 -I-10485-English.pdf > [accessed 13 April 2018]. Polish version: Układ o nierozprzestrzenianiu broni jądrowej, sporządzony w Moskwie, Waszyngtonie i Londynie dnia 1 VII 1968 r., Dziennik Ustaw 1970, no. 8, item 60.

${ }^{47}$ The programme is now called nuclear sharing. 
defined the term 'state of war' referred to in the agreements between the United States and its allies. Finally, in 1995 the NPT Review and Extension Conference made it specific that the obligations under the NPT were binding in 'all circumstances'. ${ }^{48}$ Nevertheless, worthy of note is an important element which made the transfer of nuclear weapons from the United States to, for example, West Germany different from the transfer of nuclear weapons from the Soviet Union to Poland. That these deadly weapons were stored in West Germany was made public internationally already in 1957, that is two years after the United States had transferred the first nuclear warheads. ${ }^{49}$ At that time numerous debates were held in West Germany, critical opinions were expressed and society could, in a way, show what it thought about this (for example, during elections). In the Polish People's Republic this was one of the most closely guarded secrets.

(Translated by Anna Kijak)

\section{Summary}

Drawing on the documents kept in the Polish archives, the author of the article explores the issue of the storage of nuclear weapons within Poland's territory during the Cold War. The weapons were under strict supervision of the Soviet Army, yet in case of war they were to have been made available to Polish Army units. The weapon storage programme in Poland was code-named Vistula and was one of the most closely guarded secrets of the Polish People's Republic. The article contains an analysis of the agreement (and other related documents) concluded between the Polish People's Republic and the Soviet Union on 25 February 1967 on the storage of nuclear weapons in Poland. According to the agreement, the objective was to 'increase combat readiness' of the Soviet and Polish troops. Under the agreement, three nuclear weapon storage sites were built in Western Pomerania (Templewo, Podborsko and Brzeźnica-Kolonia) by the end of 1969. From the early 1960s the Polish People's Army would expand its units capable of using such weapons. Their use was an important element of strategic planning, but in the initial period of the agreement Polish generals did not know the details of a possible transfer of nuclear warheads. It was not until the second half of the 1980s that relevant documents were drawn up to specify the ways and circumstances of a possible use of nuclear weapons by units of the so-called Polish Front (Sea Front). The nuclear weapons were removed from Poland probably in 1990.

(Translated by Anna Kijak)

${ }^{48}$ Rafał Kopeć, 'Taktyczna broń nuklearna w Europie', Przegląd Strategiczny, 2016, 9, p. 85.

${ }^{49}$ Zarychta, Broń jądrowa, pp. 232-33. 


\section{Bibliography}

Kajetanowicz, Jerzy, 'Mity w historii Wojska Polskiego w okresie Polskiej Rzeczypospolitej Ludowej', in Mity i legendy w polskiej historii wojskowości, ed. Wiesław Caban and Józef Smoliński, 2 vols, Kielce: Wydawnictwo Uniwersytetu Jana Kochanowskiego, 2014, vol. 2, pp. 355-63.

Kajetanowicz, Jerzy, Polskie wojska lądowe w latach 1945-1960. Skład bojowy struktury organizacyjne uzbrojenie, Toruń: Europejskie Centrum Edukacyjne, 2005.

Kajetanowicz, Jerzy, Wojsko Polskie w systemie bezpieczeństwa państwa 1945-2010, Częstochowa: Wydawnictwo im. Stanisława Podobińskiego Akademii im. Jana Długosza, 2013.

Kopeć, Rafał, ‘Taktyczna broń nuklearna w Europie’, Przegląd Strategiczny, 2016, 9, pp. 75-90.

Nowak, Jerzy M., Od hegemonii do agonii. Upadek Układu Warszawskiego - polska perspektywa, Warsaw: Bellona, 2011.

Piotrowski, Paweł, ‘Front Polski - próba wyjaśnienia zagadnienia', Wrocławskie Studia z Historii Najnowszej, 6, 1999, pp. 221-33.

Pompowski, Tomasz, and Paweł Piotrowski, 'Polska miała arsenał broni nuklearnej', Dziennik, 26 January 2007.

Sztab Generalny (Główny) Wojska Polskiego 1918-2003, ed. Tadeusz Panecki, Franciszek Puchała and Jan Szostak, Warsaw: Bellona, 2003.

Szulc, Tomasz, and Tomasz Nicpoń, 'Magazyny broni jądrowej na terytorium Polski', Poligon, 2007, 3, pp. 62-77.

Trubas, Michał, 'Radziecka broń jądrowa w Polsce w latach 1967-1989', in Mity i legendy w polskiej historii wojskowości, ed. Wiesław Caban and Józef Smoliński, 2 vols, Kielce: Wydawnictwo Uniwersytetu Jana Kochanowskiego, 2014, vol. 2 , pp. 276-85.

Trubas, Michał, ‘Wojska “jednorazowego użytku”. Relacja', Przegląd Historyczno-Wojskowy, 12, 2011, 2, pp. 155-74.

Zarychta, Stanisław, Broń jądrowa w kształtowaniu bezpieczeństwa 1945-2015, Warsaw: Bellona, 2016.

Bi og r a phy: Jarosław Pałka - PhD, he works at the Oral History Archives, History Meeting House, and the KARTA Centre; in his research he focuses on biographies as well as history of Polish armed forces in the twentieth century; j.palka@dsh.waw.pl. 